\title{
Catheters and sounds: the history of bladder catheterisation
}

\author{
JJ Mattelaer and I Billiet \\ Ziekenhuis Sint Maarten, Burgemeester Vercruysselaan 5, B 8500 Kortrijk, Belgium
}

Keywords: history; catheter; sounds; bladder catheterisation

The term 'catheter' is derived from the Greek word meaning to let down into, or send down. The Romans used the word demissorium or demissum or immissum, meaning 'what is brought in'. Celsus designed the instrument as a fistula, and the later Romans named it syringa. The French anatomist Riolan described it as claris vesicae, which is the word upu or 'key' for the Mesopotamians. Later on, French doctors described the instrument as algalie, a name derived from the Arab language. In the 19th century the word algalie was reserved for hard silver catheters, and 'catheter' for rubber malleable ones.

Emptying the painful, overfilled bladder must have been one of the problems of mankind since ancient times. Catheterisations were reported to have been accomplished with reeds, straws and curled-up palm leaves. The Chinese used leaves of allium. Allium is the generic name of the onion family, and the long, thin leaves are hollow. When properly dried and prepared, and sometimes covered with Chinese lack, they would have made excellent catheters. The Sumerians, the antecedents of both the Babylonians and the Egyptians, may even have used gold to make catheters. Because it is soft and malleable, gold was ideally suited for this purpose. In the Indian Vedas some catheters were described as coated with lack and lubricated with ghee (from butter). Sushruta, who invented the lithotomy position, is supposed to have used bladder catheters, but this is denied by Müller, who stated that the Hindu civilisation did not know about catheters. An outline of Persian urology is found in the Yadiguiar of Ibn Cherif, who practised in Asia Minor (probably at Broussa). Catheterisation is suggested in a passage which advises the insertion into the urethra of polished twigs of the plant tham teresi. The Greek Erasistos (310-250 BC) of Kos used an S-shaped catheter. In the excavations of Pompei, Roman metal catheters were discovered. Galen (131-210 AD) also demonstrated an S-shaped metal catheter.

The next significant step forward was a flexible, more malleable catheter by Avicenna in 1036. Avicenna was the first to insist that catheterisation should be done gently and without force. With this in mind, he designed catheters 'ex lenioribus corporibus et magis susceptibilibus flexionis' made from the skin of animals or fish, treated with a salve of white lead and ox blood, to make them firmer and lubricated with soft cheese.

Abulcasis (936-1013 AD) practised at Cordoba. His technique of catheterisation is that of Paul of Aegina (5th century AD): 'The bladder should be emptied by a slender silver catheter expanding at its outer end into a small tunnel'. Arcularius $(+1484)$ also mentioned flexible catheters made of paper, wood or leather.

But in mediaeval times the silver catheter became the most popular type. Silver was chosen for several reasons: it was easily formed, easily bent as desired, and it was said to have some antiseptic function. The catheters used by Ambroise Pare (1564) were curved over a considerable part of their length (Figure 1).

Fabricius of Acquapendente (16th century) described catheters made of silver, copper, and brass, but also of horn. He noted that: 'the Ancients made only a single orifice at the end, the moderns also at the side'. $\mathrm{He}$ also mentioned a catheter made of textile, impregnated with wax and molded on a silver sound.

Some years later the Flemish scientist Van Helmont (1578-1644) applied the same principle, but instead of textile he used chamois skin, treated on the outside with lead and linseed oil. He introduced this catheter with the help of a stylet, made of whale bone. This allowed him to catherise the same patient forty times a day!

Later on, the woven catheter was produced, and the

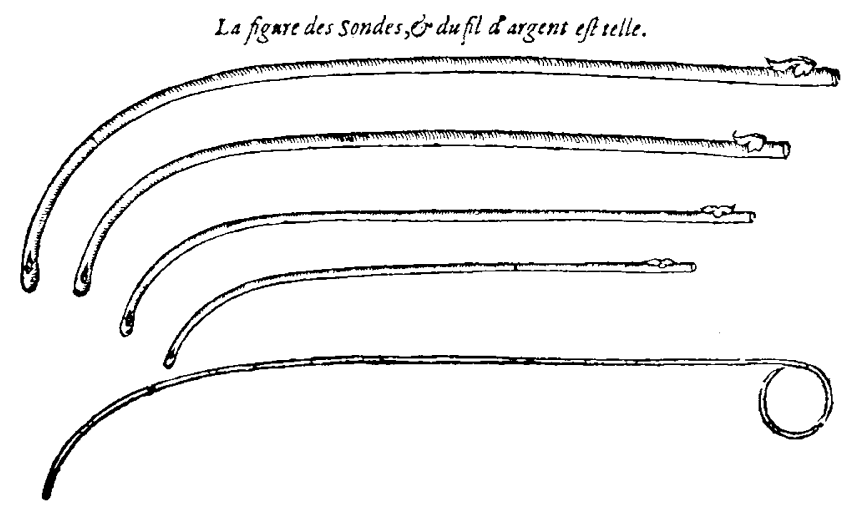

Figure 1 Catheters (from Ambroise Paré: Dix Livres de la Chirurgie, 1564) 
silk woven varnished catheter is its direct descendant. Woven catheters were of tubular construction, soaked in linseed oil and then dried.

Scultetus (1595-1645) of Ulm described and illustrated various surgical procedures, including catheterisation in his well known Armamentarium Chirurgicum. It is interesting to note that in mediaeval times, and even in the Renaissance, catheterisation was done in the upright, kneeling or sitting positions (Figure 2).

Like many surgeons of this period Saviard filled the eye of his catheter with butter to prevent the entry of blood during its passage.

The silver woven, coated catheter is of course much smoother, more regular and more readily produced. So is the catheter made of flat silver wires, spirally wound by the Dutch surgeon Van Solingen and described in his book Manuale Operatien der Chirurgie (1684). The Dutch translation by Hendrik Ulhoorn of Laurens Heister's book Heelkundige Onderwijzingen (1776) also describes a silver catheter.

In 1752 Benjamin Franklin described a silver catheter to his brother: 'It might be flexible, but must be covered with a 'fine gut', or rubbed with tallow to fill the joints'.

Catheterisation with a metal catheter was extremely difficult, and was known as 'tour de maître' (attributed to Mareschal), or 'tour sur le ventre' and only a few doctors and surgeons were able to perform this 'tour de maître'

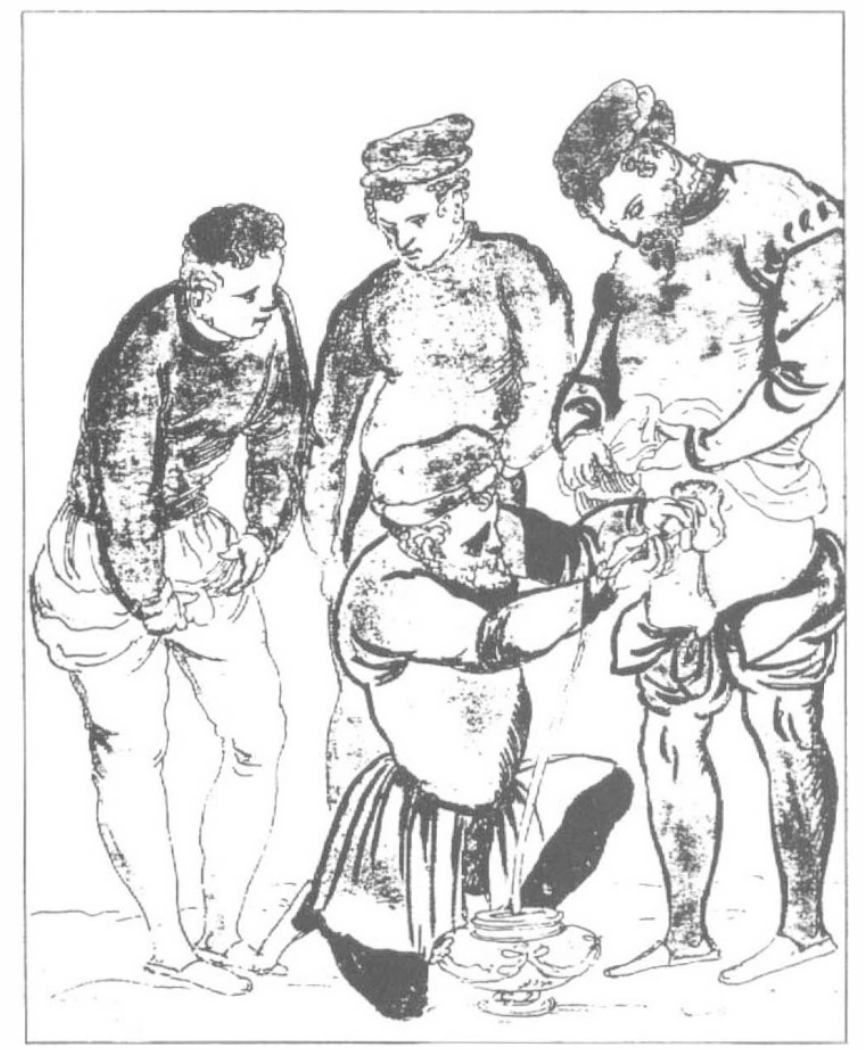

Figure 2 In mediaeval times, and even in the Renaissance, catheterisation was done in the upright, kneeling or sitting position
JL Petit (1674-1750) invented a catheter with a double curve, but it was in fact Louis Auguste Mercier (1811-1882) who in 1836 invented the coudé catheter and in 1841 the bicoudé catheter. (Coudé means 'elbow' in French) (Figure 3). Both were metal catheters. The coudé catheter provoked a lot of discussion since a few years later Leroy pretended that he was the real inventor of the coudé catheter which he did not name 'catheter à courbure' like Mercier, but 'à toute petite courbure ..... And in 1857 the British journal The Leech, in Cardiff, published a biography with a picture of Emile Coudé as the inventor of the bicoudé catheter! This was strongly contested by a letter in the British Medical Journal and followed by another letter published in The Lancet from a certain Hercule Coudé who pretended that Emile Coudé was not only his uncle but the real inventor of the Coudé catheter. Howard Hanley pretended later that the real inventor was not Monsieur Coudé, but his half brother Bicoudé.

In $1875 \mathrm{JJ}$ Cazenave published a detailed monograph on his experiments with catheters, extending over a period of 20 to 30 years, with whale bone, narwal tusks, and ivory tubes, and finally succeeded in producing a flexible and smooth catheter of real ivory, conforming to the shape of the urethra.

The introduction of catheters made of elastic gum or rubber was an important step forward (Figure 4). Herissand in France suggested that rubber might be used for the manufacture of catheters and Troja, an Italian surgeon, tried to put this idea into practice, but

1
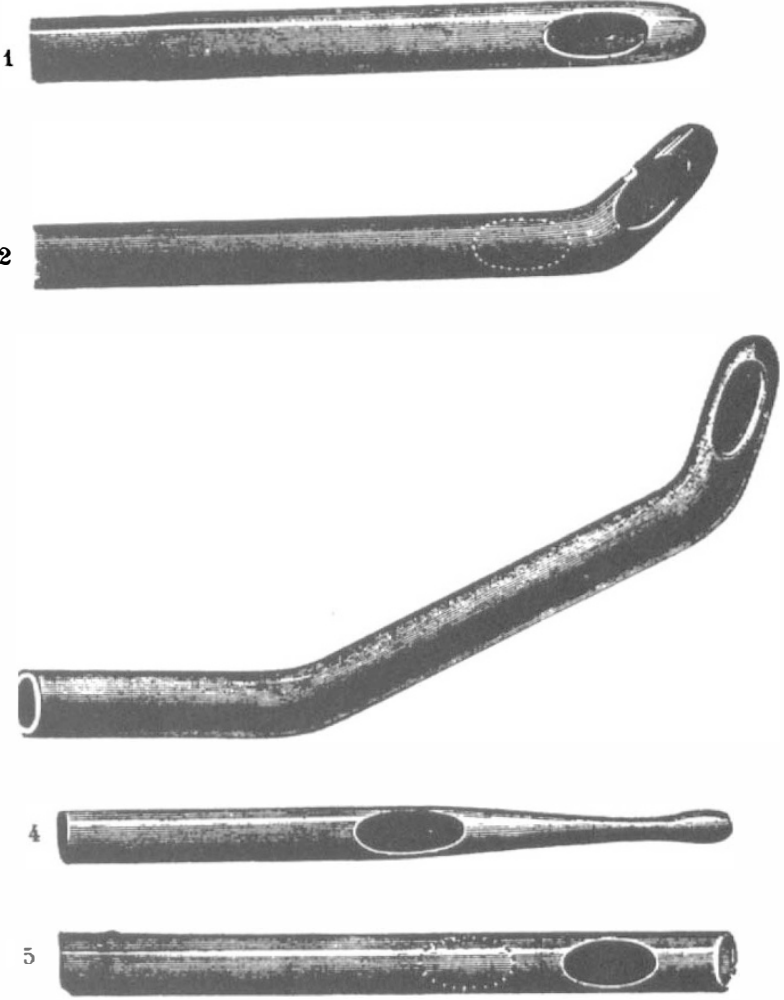

Figure 3 Early coudé and bicoudé catheters, depicted in an Eynard catalogue, were introduced by Mercier and Petit 


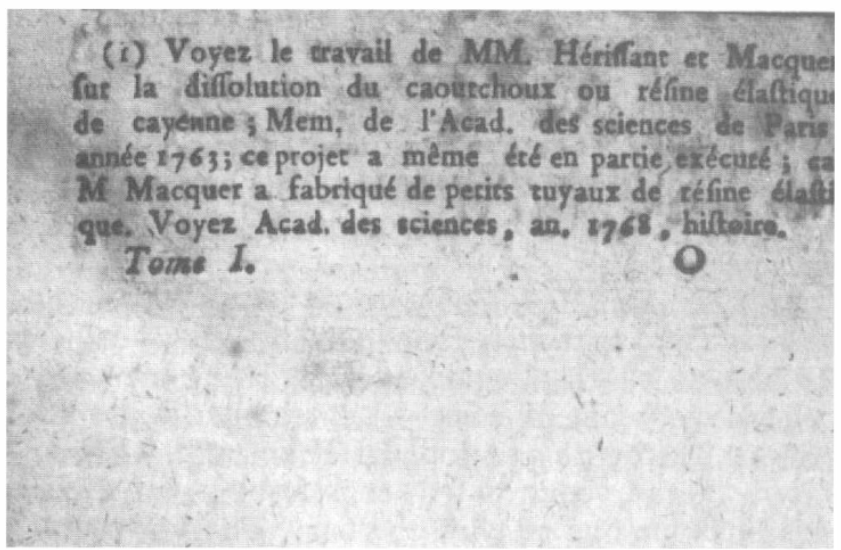

Figure 4 Text relating to the suggestion that rubber might be used for the manufacture of catheters. (In: Deschamps JFL, Traité Historique et Dogmatique de l'Opération de la Taille. Paris, 1796)

without success. In 1768 Macques had the same idea, but it was a silversmith in Paris named Bernard who had the idea to cover and impregnate a woven silk cylindric tube with rubber. Still this first rubber catheter was of very poor quality because it became weak at body temperature and friable and rawfaced by air contact. Fragments remained in the bladder and there was a lot of encrustation. Rubber could not be formed and shaped as desired until 1839 when Goodyear invented vulcanisation. By this vulcanisation technique the properties of firmness, flexibility and durability could be improved.

At the hospital St Louis in Paris, Auguste Nelaton (1807-1873) had seen the value of this new process, and Goodyear's vulcanisation process was used to produce what is still known and used as the Nélaton type of catheter of red rubber, with a solid tip and one eyed (Figure 5). The 'sondes en caouthouc rouge' of Nélaton had a narrow lumen and could not be used for a long time because the rubber became hard and friable. The rubber catheter was subsequently perfected and patented for commercial use by James Archibald Jacques, manager of a rubber factory in England.

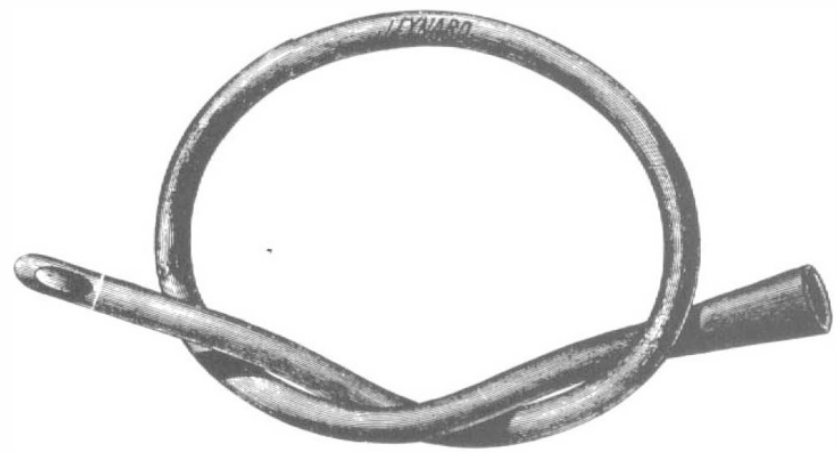

Figure 5 Nélaton's straight rubber catheter as it appeared in an early Eynard catalogue
In the United States it was not until 1883 that Petrie, a Frenchman of Philadelphia, began to manufacture catheters. Roy, a son in law of Benas, a Parisian instrumentmaker, established a catheter factory in a suburb of New York City around 1879. The business closed about 11 years later. George Tiemann and Company of New York City became the first major manufacturer of rubber catheters in the US around 1876. By 1893 about one half of the one million catheters and bougies used annually in the US were produced domestically.

Once the use of rubber and gum elastic catheters became widespread and production increased, some method of standardisation became necessary. Joseph Frederick Benoit Charriere, a French instrumentmaker and a contemporary of Nélaton developed the French scale, still the most widely used today, based on the metric system, and promulgated by the French Academy of Science in 1799. His scale was based on one third of a millimeter in the diameter of a bougie being equal to one unit in size. Thus a $1 \mathrm{~mm}$ catheter is a no. 3 French (Figure 6). The system was modified a few years later by Benique. He based his scale on one-sixth of a millimeter so that a no. 1 charrière was equal to a no. 2 béniqué. The English, who always seem to like more complex measurement systems, had a scale based on differences of one sixty-fourth of an inch in diameter, which was known as the Weiss gauge (after one of the leading instrument makers of this period). Sir Henry Thompson, the English father of urology, when advocating adoption of the French scale as being more precise said: 'We must be cosmopolitan and tolerant'. And so in 1922 the Weiss gauge scale was changed and the English also employed the metric system. It was based on a scale of $0.5 \mathrm{~mm}$ in diameter, beginning with a no. 1 English equal to $1.5 \mathrm{~mm}$ in diameter.

One of the requested developments was a catheter that could be retained in place through its own configuration. Most indwelling catheters were taped or tied to the penis in men, and they were sometimes sewn to the urethral orifice in women (Figure 7).

In 1822 Theodore Ducamp used inflatable bags on his dilating bougies. The bags were formed of Goldbeater's skin, a submucosal layer of the intestine of oxen. In about 1841 Reybard designed a self-retaining catheter. One part was held in place by a movable flange and the other part fitted with a small inflatable

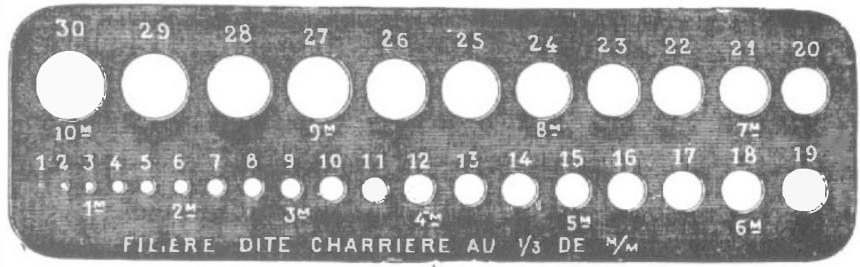

Figure 6 Efforts to standardise the sizes of urological instruments led to Charrière's scale based on one third of a millimeter. In the US this scale is known as the French scale 


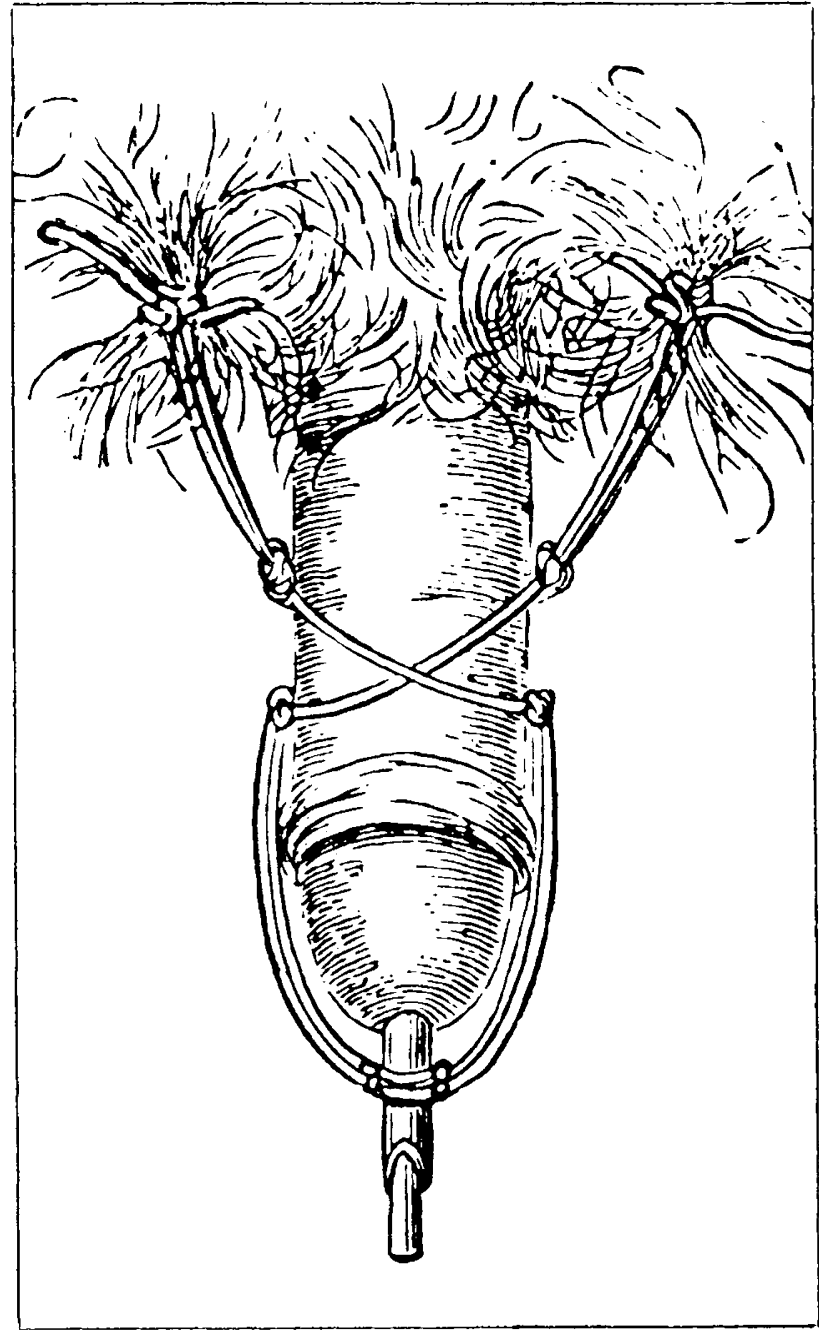

Figure 7 Thompson, the father of urology in Great Britain, suggested this uncomfortable method of keeping a catheter in place

balloon: the prototype of the Foley catheter. It was published in his book: Traité Pratique de Rétrécissements du Canal de l'Urèthre (Paris 1853) and was introduced as 'sonde à fixation automatique'. Later on, self-retaining catheters were designed by Lebreton, Desnos, Holt and Dowse.

In 1872, JJ Wright, a surgeon from Halifax in Yorkshire (England), designed a rubber catheter with flexible shoulders. It was not until 20 years later that De Pezzer gave an account of his mushroom-ended catheter at the Congrès Français de Chirurgie (1890). Two years later, in 1892, Malecot, a senior intern of Felix Guyon described the 'sonde se fixant d'elle-même à demeure dans la vessie', a wing-tipped catheter known by his name. Numerous other self-retaining catheters were described during the early part of the 20 th century. John R Herman mentioned having made a $5 \mathrm{cc}$ self-retaining catheter in 1927 by tying a balloon made of profylectic rubber to a two-way woven catheter (the idea of this catheter came from Dr
Vincent Odolo of Providence, Rhode Island). In use, this catheter proved impractical as the quality of rubber available at that time caused the balloon to disintegrate very soon after coming into contact with the urine in the bladder.

It was not until latex rubber became available in the early 30 s that the $5 \mathrm{cc}$ balloon self-retaining catheter became practical.

In 1929 Dr FEB Foley of St Paul, Minnesota, ordered Bard to make a longitudinally-groved catheter for him, to which he attached an inflating tube and a balloon by means of a fine silk thread and waterproof cement. During this period, Dr Thomas M Jarmon of Tyler, Texas, contributed considerably by a very ingenious method of tying the bags. The first balloon catheter commercially manufactured and sold was presented to the profession by $\mathrm{Dr}$ Hobert Dean Belknap of Portland, Orgeon, in an article published in 1933 in the Urologic and Cutaneous Review. This catheter was manufactured by a mechanical rubber molder in Portland and distributed by Bard. During the same period, the Anode Company, with the help of Dr Foley, produced a practical balloon catheter, now known as the 'Foley'. This was published in the Journal of Urology in July 1937: 'A self retaining bag catheter for use as an indwelling catheter for constant drainage of the bladder'.

Prior to the advent of prostatectomy the patient was usually condemned to a 'catheter life'. Patients with persistent retention were taught to carry out the procedure themselves. The necessary requisites consisted of a catheter and lubricant, which could be carried in a pocket case, a walking stick or other container: 'Patients carry in their walking sticks or umbrellas but one catheter'. A cabinet of elaborate apparatus was designed for the use of the affluent patient at home. Henry Thompson referred to two patients, one of whom, aged 90 , had been catheterising himself for 22 years, while the other had catheterised himself 35000 times. Even in 1893 Buckston Browne maintained that as long as the catheter life was tolerable to the patient, prostatectomy should not be performed.

The expression 'catheter fever' was first used by Andrew Clark in 1833, to describe episodes of febrile illness in men with prostatic obstruction treated with catheters. One of the earliest descriptions of a systematic approach to reduction of infections due to the indwelling catheter was reported in 1928 by Cuthbert Dukes working at St Marks Hospital in London. He developed an intermittent irrigation device in which the catheter was attached by a Y tube to a sterile closed drainage bottle. In addition, periodic irrigation with oxycyanide of mercury (1/500) was used to wash the system.

Tidal drainage was originally introduced by Laver but in 1947 was promoted by Munro in Boston. By the periodic filling of the bladder Munro tried to recover the atonic detrusor muscle sufficiently to increase the capacity of a hypertonic bladder.

Since World War II, the majority of centres in the 
United States, practised bladder training with an indwelling catheter and tidal drainage. Over the years, however, most of the centres abandoned tidal drainage in favour of other procedures, such as Bors blocking procedures which expedited the return to an upper motor neuron type of bladder. While in the United States bladder training was performed since 1947, intermittent catheterisation with a 'non-touch' technique was being practised at the Stoke-Mandeville Spinal Injuries Centre in England by Ludwig Guttmann. The non-touch technique must be performed by a physician who is surgically scrubbed and dressed; intermittent catheterisation under that technique is performed every $6 \mathrm{~h}$.

In 1958 Paul Beeson published his landmark editorial entitled: 'The case against the catheter'. From 1970 'clean intermittent self catheterisation' was introduced and popularised by Lapides. By this method the patient learned to catheterise him or herself, so that this method could also be applied without specially trained staff, and could be performed ambulatory.

In recent years suprapubic drainage began to become popular as an alternative to drainage through a urethral catheter. Routine suprapubic drainage was first done in gynaecological surgery, but was soon extended to general medical patients. The first devices of trocart cystostomy were published in 1966 by Taylor and Nickel, and Hodgkinson and Hodari, followed by the Bonnano suprapubic drainage catheter with a coiled tip. The Cystocath drainage system (Reif design), obtained from Dow Corning Corporation, Midland, Michigan was the first available commercialised set.

Today, when a nurse gives a patient a sterile well packed disposable catheter in plastic or silicone, it is difficult to imagine how comfortable it is, both for the urologist and for the patient. It is good to know and to appreciate how difficult and how painful catheterisation of the bladder was until only a few decades ago.

\section{Bibliography}

1 Bors E, Comarr AE. Neurological Urology: Physiology of Micturation, its Neurological Disorders and Sequelae. University Park Press, 1971, pp 224-226.

2 Cazenave JJ. Histoire Abrégée des Sondes et des Bougies Uréthrovésicales Employées jusqu'à ce Jour. Ballière JB et Fils, Paris, 1875.

3 De Schamps JFL. Traité Historique et Dogmatique de l'Opération de la Taille. Paris, 1796.

4 Desnos E. L'Histoire de l'Urologie. Doin Editeur, Paris, 1914.

5 Foley FEB. A self-retaining bag catheter for use as indwelling catheter for constant drainage of the bladder. J Urol 1937; 38:
$140-143$

6 Gutmann L, Frankel H. The value of intermittent catheterisation in the early management of traumatic paraplegia and tetraplegia. Paraplegia 1966; 4: 63-84.

7 Herman JR. Catheters. In: Urology: A View through the Retrospectroscope. Harper and Row Publishers: Hagertown, MD, 1973, pp 35-40.

8 Hodgkinson CP, Hodari AA. Trocer suprapubic cystostomy for postoperative bladder drainage in the female. J Obstet Gynecol 1966; 96: 773-786.

9 Heister L. Heelkundige Onderwijzingen, Bewerkt door Hendrik Ulhoorn. 't Amsteldam voor rekening van Isaac Buyn, 1776.

10 Helmont JB. van. Dageraad ofte Nieuwe Opkomst der Geneeskonst. Tot Rotterdam By Joannes Naeranus, Boekverkooper op 't Steiger in den Boek-binder, 1660.

11 Holt B. Holt's winged india-rubber catheters for retention in the bladder (letter). Lancet 1970; 1: 399.

12 Howlett EH. A new form of guide catheter. Lancet 1882; 1: 60.

13 Kuss R, Gregoir W. Histoire Illustrée de l'Urologie de l'Antiquité à nos Jours. Editions Roger Dacosta: Paris, 1988, pp 195-206.

14 Lapides J, Diokno AC, Silbek SJ, Lowe BS. Clean intermittent self-catherisation in the treatment of urinary tract disease. Trans Am Assoc Genito-Urin. Surg 1971; 63: 92.

15 Lapides J, Diokno AC, Lowe BS, Kalish MD. Follow-up on unsterile, intermittent self-catherisation. J Urol 1974; 111: 184.

16 Laver $\mathrm{CH}$. Quoted by Munro D and Hahn J (23) and Bors E (1).

17 Lytton B. Catheters and Sounds. Perspectives in Urology, Vol 1. American Urological Association Inc., Hoffman La Roche Inc: Nutley, NJ, 1976; 119-134.

18 Malecot A. Sonde se fixant d'elle même à demeure dans la vessie. Arch Tocologie Gynécologie 1892; 19: 321-323.

19 Mercier LA. Mémoire sur les sondes elastiques et particulièrement sur les sondes coudées et bicoudées. Gaz. Méd. Paris, 3rd series 1863 ; 18: 365-367.

20 Mercier LA. Note sur de nouvelles sondes et bougies. Bull Acad Méd 1846; 30: 934.

21 Moonen WA. Iets over de geschiedenis van de catheter. Ned T Geneesk 1969; 113: 1201-1204.

22 Muller RFG. Die Sagen vom Katheterisieren der Inder bei Harnverhaltung. Sudhoffs Arch Gesch Med 1958; 42 : 377.

23 Munro D, Hahn J. Tidal drainage of the urinary bladder; a preliminary report of this method of treatment as applied to 'cord bladders' with a description of the apparatus. $N$ Engl J Med 1935; 212: 229.

24 Munro D. Rehabilitation of patients totally paralysed below waist, with special reference to making them ambulatory and capable of earning their living: III Tidal drainage, cystometry and bladder training. $N$ Engl J Med 1947; 236: 223-235.

25 Murphy LJT. The History of Urology. Charles C. Thomas Publisher: Springfield Illinois, USA, 1972, pp 69-74.

26 de Pezzer. Nouvelles sondes uréthrales et vésicales en caoutchouc pur, très flexibles. Congrès Français Chirurgie 1890; 5 675-681.

27 Reybard JF. Traité Pratique des Rétrécissements du Canal de l'Urètre. Labe, Paris, 1853.

28 Taylor BD, Nickel JE. Suprapubic cystostomy and the use of polyethylene tubing. J Obstet Gynecol 1966; 28: 854-856.

29 Thompson Sir H. Clinical Lectures on Diseases of the Urinary Organs, 8th edn. HC Lea: Philadelphia, 1869, pp 97-98.

30 Wright JH. New self-retaining catheter. Lancet 1872; 2: 670. 